\title{
ICT and Learning Attitude towards Students' Academic Paragraph Writing in College Level
}

\author{
Rita Hayati \\ Universitas Sriwijaya \\ ritahayati@fkip.unsri.ac.id \\ Hesti W. Anggraini \\ Universitas Sriwijaya \\ hwanggraini@fkip.unsri.ac.id \\ Hariswan P. Jaya \\ Universitas Sriwijaya \\ hariswan@fkip.unsri.ac.id
}

ABSTRACT

The use of technology has been growing rapidly in the recent years. Technology applies to support the success of language learning, for example, providing web-based learning, mobile-based learning, educational videos, stimulation, online learning platforms, and many more. Learning attitude also determines to achieve the language learning goals. Then, the complexity of English writing causes the students' denial to take English writing class. This study aimed at finding out whether there was significant correlation among ICT writing. Seventy-one students of English Education Study Program got involved in this correlational study. The data were gained from primary and secondary sources; those are a 15-item ICT use questionnaire, a 20 -item learning attitude questionnaire and documentation of students' writing. The findings reported that there was significant correlation among the three variables statistically since the significant value was $0.006(<0.05)$. The value of adjusted $\mathrm{r}^{2}$ was 0.114 which means ICT use and learning attitude contributed $11.4 \%$ to the students' English academic paragraph writing.

Key words: ICT, learning attitude, academic paragraph writing 


\section{INTRODUCTION}

The use of ICT in the $21^{\text {st }}$ century has increased rapidly in order to help students learn more effectively and help teachers to finish the tasks more efficiently (Selwyn, 2003). More importantly, ICT is a powerful tool in presenting or representing information in various ways. ICT includes computers, the internet, and any electronic device which functions as telecommunication and information equipment. In these years, an internet plays its best to increase efficiency and effectiveness in all levels of education and enhance the transformation of education for the better (Tinio, 2002; UNESCO, 2002). In addition, Dudeney (2000) stated that the potential benefits of using ICT as a means of developing English language skills has received much attention. ICT also has the potential to be a means of communication that requires collaboration. ICT facilitates various forms of online conferences and virtual discussion that most helps teachers do online evaluation.

Technology is being used in the 21st century, where teaching and learning takes place, and when education has to be developed with some various teaching strategies. It is a key component of a sophisticated classroom; however, there will be no meaning in the teaching and learning process if teachers and students do not apply it. Teacher must know to operate ICT in teaching and learning process. There are many way to improver their ability in using ICT such as following ICT training (Apriani, etl.al, 2021). This means that technology is not feasible if left untouched and used by teachers and students. It is a cyclical process in which they are constantly being dynamic to shift and change from time to time (Inderawati, 2017).

In educational settings, there are two different ways for learners to have access to technology: learn from technology and learn with technology (Reeves, 1998, cited in Inderawati, 2017). Therefore, both teachers and students can utilize the internet like using social media to be applied in teaching and learning process. In addition, Başal \& Aytan (2014, cited in Indrawati, 2017) argue that rapid advances in ICT in recent years have resulted in extensive searches for possible uses of ICT in education settings. ICT is not also improve students'achievement (Apriani and Hidayah, 2019; Apriani, 2017) but also students' character (Apriani, 2016; Apriani, et.al.; Apriani, et.al, 2019). Many educators around the world, including English teachers, are now taking innovative steps to integrate technology into their teaching environment. In 
language teaching, language teachers have various options for integrating technology into their classroom. In line with this, some previous researchers have investigated the important roles of technology in learning English (Inderawati, 2011; Fajri, Inderawati, Mirizon, 2015; Inderawati, Petrus, \& Jaya, 2019).

In particular, technology-based teaching and learning offers various interesting ways including educational videos, stimulation, data storage, use of databases, mind mapping, guided discovery, brainstorming, music, and the World Wide Web (WWW) which will make the learning process even more satisfying and meaningful (Finger \& Trinidad, 2002). Similarly, Inderawati, Sofendi, Purnomo, Vianty, \& Suhendi (2019) had utilized technology for learning supports to the preservice EFL teachers' engagement by showing many things to involve: class management, equipment, application, instructional material, supporting crew, place and instructors' relation in learning activities. Furthermore, according to Toomey (2001, p. 3), "This technology can include hardware (e.g computers and other devices); applications and software connectivity (e.g. access to the internet, local network infrastructure, and video conferencing)." Thus, the students are not limited to a specific curriculum and assistance will be limited as ICT will be aimed to support teachers to creatively plan approaches and lessons that had a big impact which will encourage students to be actively involved in learning.

Learning attitude is believed to influence behavior such as reading books, writing, and speaking foreign languages. According to Kara (2009), learning attitude other than opinions and beliefs has a clear influence on student's behavior and its impact on their performance. It is said that the students who have positive beliefs about language learning has tendency to promote more positive attitudes towards language learning. In study, if students have a positive attitude towards any subject, they can benefit greatly in many ways in certain fields. Other than that, Gajalakshmi (2013, p. 1) states that attitudes are determined by individual beliefs about the results or attributes of performing the behavior (behavioral beliefs), weighted by evaluation against the result or attribute. Someone who has a firm belief will have a positive attitude. As a result, it gives good impacts on student's performance.

Kara (2009) stated that learning attitude had a clear influence on student's behavior and its consequences on their performance. 
Dehbozorgi (2012, p. 44) in his research on EFL students majoring in English Translation Department in Iran found that result mostly participants received high scores for their attitudes. About $90 \%$ of them have an attitude positive towards learning English.

In learning English, writing is a basic language skill and very important. Writing is one of the productive skills that must be mastered by students. Writing is the most difficult skill to be mastered by foreign language learners. Muslim (2014) says that writing is more complicated and challenging than other language skills. The main reason for this difficulty is the fact that writing is a very complex process that involves creation and organizing ideas and translating them into cohesive text. Thus, writing skills are one of the media for communicating with others through writing that students can convey some information, express their ideas, thoughts, feelings and opinions.

Following these findings, the researchers found a gap to do this research. More in-depth research should be conducted to get a better understanding of the use of ICT in line with the students' learning attitudes in writing class. Because the study is needed not only to hear what the students feel, but also to reflect the writing classroom activities. To determine the existence of ICT in language learning, the link between the two variables is importantly viewed since it directly creates mutual relationship to the quality of students' writing.

In this case, there are several reasons. First, writing strengthens the grammar structure, idioms, and vocabulary items that have been studied by students. Second, when students write, they have the opportunity to develop their knowledge, and they will learn many things, such as rules of the writing itself and the arrangement of words and sentences. Third, when students write, they need to use a new language, the utmost effort to express ideas, and constant use of their eyes, hands and brain. One can express ideas and their thoughts in speaking and writing but they need to be mastered to convey the idea.

However, the ability of Indonesian students to write is still low. According to Abas and Aziz (2016), most students in Indonesia find it difficult to express their ideas in English. In addition, Aryanika (2016) stated that several students find it difficult to write, because they do not just have low vocabulary mastery but also low motivation in writing and rarely build their confidence in writing it. It can be assumed that Indonesian students' difficulties in writing are related to difficulties in 
expressing ideas, low vocabulary mastery, and low motivation in writing. This matter affects students' writing skills while in college.

There are several factors that influence student's writing difficulties in Indonesia. This includes differences in culture, structure, and grammatical terms between Indonesian and English. Ariyanti (2016) stated that it is quite difficult to master writing, especially for EFL students in Indonesia. It is caused by the differences between Indonesian and English, such as structural and grammatical terms and styles. In addition, other factors that affect students' difficulty in writing are dealing with grammar and vocabulary. EFL students must use correct English grammar and vocabulary, apply the writing skills they have learned, and incorporate this knowledge with their previous experience on a given topic while writing.

Writing achievement is the student's ability to express their knowledge, ideas, thoughts, skills, and feelings in writing ones measured by a writing test. From writing achievement, students will see the improvements in their writing or not. In addition, Nunan (1999, p. 271) states that writing is probably the hardest thing to do in language. Also, writing is one of the main skills in language learning and is used as a means of transferring the author's knowledge to the people. Writing is a skill that requires learning and practice. Writing refers not only to written texts but also to the process of thinking, composing, and encoding the language into the text. One of the student's goals is to produce good writing called their writing achievement. Moreover, proven with research conducted by Aunurrahman, Hamid, and Emilia (2016) claim that the practice of academic writing is not easy for students. This suggests that to master writing is often a challenge in mastering the English language.

The writing achievement referred to in this study is the result of students' paragraph writings which are assumed to be good based on the results of interviews with several lecturers teaching these subjects. According to one of the teaching lecturers, he always does reflection at the end of the semester to get feedback from students.

Results of an interview stated by Setyowati \& Sukmawan (2016) also reveal that although students have moderate attitudes towards writing, they perceive writing as difficult, and stressful. While those with high attitudes, mostly views writing as interesting and challenging. These findings also revealed some efforts students made to improve their 
writing skills, including writing practice, reading a lot for knowledge and ideas, and use diary writing.

This study aims to see the relationship among ICT use, learning attitude and students' academic paragraph writing. The results of this research are expected to be useful for: (1) students, the existence of learning attitude and ICT can improve learning achievement; (2) the teacher, contributes to efforts in improving learning outcomes especially in English; and (3) educational institutions as an alternative effort to increase learning quality and teacher competence.

\section{THEORETICAL FRAMEWORK}

\section{The Use of Information Communication and Technology}

Several studies reveal that there are factors that influence implementation of ICT in the classroom, especially in terms of assessing student's assignments authentically. According to Venkatesh and Davis (2000), when teachers are presented with technology in teaching activities, there will be variables that represent the problems faced by the teachers. Variables are limited to ICT facilities, limited to accessibility, and network connections, lack of effective training and limited time.

Many studies reveal certain reasons about inadequate access to technology. Sicilia (2005) states that a teacher often criticized the difficulty of accessing ICT tools. One of the reasons mentioned as "computers must be bespoke and teachers will forget to do so, or they cannot order it for several consecutive periods when they want to work on some project with students"(p. 50). To explain, ICT tools will be difficult to access and there will be sufficient time to implement ICT-based materials because teachers have to take turns using computers or other ICT tools. However, Becta (2004) states that a number of plausible factors cause problems to access the technology, such as lack of organizational management, lack of individual access to ICT for teachers, and the poor condition of devices and the internet and operating systems.

Technology assistance and resources in schools need to be managed properly for preventing unexpected obstacles to be experienced. Pelgrum (2001) found that one of the dominant barriers to using ICTs is inadequate technical assistance. Likewise, Sicilia (2005) too noticed that poor technical support contributed to bottlenecks primary 
for teachers. According to him, "Technical obstacles hamper the smooth delivery lessons or the natural flow of classroom activities "(Sicilia, 2005, p. 43). Technical bottlenecks can be downgraded to slow website loading, no internet connection, computer obsolete and damaged, malfunctioning printers, and other technological aids.

\section{Learning Attitude}

The word attitude, which comes from the Latin word "aptus" which means conformity or adaptation, means behavior, circumstances and behavior lines. If someone has a good attitude, it will affect his character, his emotions and also his behavior. Attitude, of course, will affect students' learning attitude and their achievement. If students learn something, it is better if they have a good and positive attitude. Students are expected to have a positive attitude towards learning. When students build a positive attitude toward subject, they enjoy the material and are motivated to do and learn because they do it with pleasure, enjoy, and are interested in the subject. Gajalakshmi, (2013, p.1-2) states accordingly, the concept of attitude is divided into three components, namely, behavior, aspects of attitude related to the way a person behaves and reacts in a certain situation. In fact, successful language learning requires learners to identify themselves with native speakers and acquire or adopt various aspects of characterizing behavior in a target language community member. Aspects of cognitive involve language learners' beliefs about their received knowledge and understanding them in the language learning process. Cognitive attitudes can be classified into four steps linked to the previous and the new knowledge, creating new knowledge, checking for new knowledge, and applying new knowledge in most situations. The second is aspect of emotional. Feng and Chen (2009) stated that the learning process is an emotional process. It is influenced by various emotional factors. Teachers and students are involved in various emotional activities and various emotions are produced. Attitudes can help students to express whether they like or dislike the objects or situations around them. It is agreed that the inner feelings and emotions of learners influence their perspectives and attitudes against the target language (Choy and Troudi, 2006).

Learning attitude has a big impact on the student's learning process. According to Dehbozorgi (2012, p.42), attitudes can play a very important role in language learning because they can influence the success or failure of students in their learning. Moreover, Gajalakhsmi 
(2013) stated that, both a negative and positive attitude has a strong impact on successful language learning. Moreover, Ajzen (2005) believes that attitudes, such as personality traits, are hypothetical constructs that are inaccessible for direct access and must be inferred from measurable responses. From the statement below, experts try to explain that learning attitude has a strong impact of language learning process. Students need to have a good and positive attitude in learning to achieve their success in learning. Ideally, students must have a positive attitude towards writing because it can help them to achieve writing achievement better. Based on previous research, there is a positive relationship between attitudes and writing skills (Hashemian \& Heidari, 2013). Research result also shows that students who have integrative motivation achieve better success in second language academic writing than those who have an instrumental motivation. In addition, Graham et al (2007) did study on students to find out their attitudes towards writing and writing achievement. They know that students who have a more positive writing attitude will have better writing achievement than other students.

\section{Academic Paragraph Writing}

Writing is the expression of ideas, thoughts, and stories on a sheet of paper. When we write, we put down our thoughts, ideas and feelings; sometimes we put down emotions on it. For some people, writing may be difficult even in their first language. It may be more difficult for them to write in their foreign language or second language. For students, writing may not be their first choice when they take English subjects. Several factors influence their writing achievements from internal and external factors. For example, from the internal factor, they have no desire to write happily and for the external factor, it comes from their teacher. That is, if the teacher can handle the class, students can definitely have a high interest and a good attitude in writing. Oshima \& Hogue (2007, p. 15) argue that some people believe that writing cannot be taught because writing includes complex aspects to it. However, these skills can be taught if the teacher knows how to handle it.

Writing achievement is the student's ability to express their knowledge, ideas, thoughts, skills, and feelings in writing ones measured by a writing test. From writing achievement, students will see an increase in their writing or not. In addition, Nunan (1999, p. 271) states that writing is probably the most difficult thing to do in language. Oshima and Hogue (2007, p.15) argues that writing was an action that requires 
several processes such as thinking, writing, reading, correcting and revising. That is not a simple step because people must be aware that what they are writing is what they want to say or express.

\section{Previous Related Studies}

Several previous studies support this research. First, Bidin (2009) in his study analyzed the correlation between attitudes and learning outcomes in Malaysia. The findings of this study stated that there is a significant relationship between attitudes towards learning English and learning outcomes. Phenomenon found that many students in this school have no interest in learning English.

Hamzah, Embi \& Ismail (2020) conducted a study about the investigation of the impact of technology change in Malaysian Smart Schools on students of Islamic Education. The study reported that he attitudes of students are very positive towards the current change in Smart Schools. Most of the students use computers weekly or monthly (61\%), $12 \%$ of them can be categorized as heavy users as they use computer every day.

Furthermore, Mustafa and Rashid (2015) found that students' interest in learning English at a certain level affects their learning outcomes. The more positive the student's interest is, the greater the student's motivation to learn English. It was found that strong academic performance confirms a positive mindset, increases persistence, and strengthens strong academic behavior, high student motivation, both extrinsic and extrinsic. At last, it causes high student's persistence in learning English as a foreign language.

\section{RESEARCH METHODOLOGY}

The research used correlational study as seen in the picture as follows:

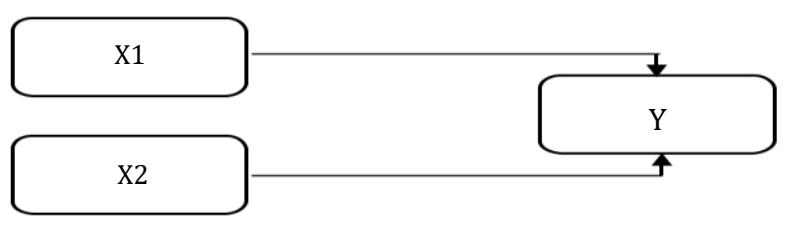

Figure 1.

Research Design 
Notes :

$$
\begin{aligned}
& \mathrm{X} 1=\mathrm{ICT} \text { Use } \\
& \mathrm{X} 2=\text { Learning attitude } \\
& \mathrm{Y}=\text { Academic paragraph writing }
\end{aligned}
$$

This research was conducted in English Education Study Program, FKIP Universitas Sriwijaya academic year 2019/2020. The sample of this study was 71 third semester students. The researchers used purposive sampling technique on the basis of the research objectives. For data collection, the researchers distributed two different questionnaires. A 15 item ICT use questionnaire was used to know the students' use of ICT in academic paragraph writing. The questionnaire consists of eight positive statements and seven negative statements. Then, a 20-item learning attitude questionnaire was aimed to know the students' learning attitude in writing. This questionnaire covers a 4-Likert scale statement (strongly disagree, disagree, agree, and strongly agree). It was adapted by Podsen (1997). Documentation of students' writing was used as a secondary data source in order to know the students' writing achievement.

To answer the research questions, the researchers conducted correlational study. To find out the significance of the relationship between the two variables, it is calculated by using a statistical test at the significant level of 95 and the largest error rate $(\alpha)$ of 0.05 or $5 \%$. With the following criteria: (1) there is a significant relationship between the independent variable and the dependent variable if $\rho$-value $\leq \alpha(0.05)$; and (2) there is no significant relationship between the independent variable and the dependent variable if $\rho$-value $>\alpha(0.05)$. Last, to find out the contribution, multiple regression analysis was applied.

\section{FINDINGS \& DISCUSSIONS}

\section{FINDINGS}

\section{The Result of Students' Writing Achievement}

In this study, the researchers used documentation of the writing score to know students' writing achievement. The documentation was taken from the administration of the English Education Study Program 
FKIP UNSRI. The highest possible score achieved by the students would be 100 and the lowest would be 0 . After the researchers took the data and arranged the value, the highest score was "94" and the lowest was "75". The mean of the data was 85.39 and the standard deviation was 2.925. Then, the researchers analyzed the result of Paragraph Writing score based on the score categories. The categories are A (excellent), B (good), C (enough), D (poor), E (failed). See the following table.

10 | ENGLISH FRANCA, Vol. 4, No. 2, 2020

\section{Table 1.}

Category of Writing Achievement

\begin{tabular}{|l|l|l|l|}
\hline \multicolumn{1}{|c|}{ Score } & \multicolumn{1}{|c|}{ Category } & \multicolumn{1}{c|}{$\begin{array}{c}\text { Number of } \\
\text { Students }\end{array}$} & $\begin{array}{c}\text { Percentage } \\
\text { (\%) }\end{array}$ \\
\hline $86-100$ & A (Excellent) & 45 & 63.4 \\
\hline $71-85$ & B (Good) & 26 & 36.6 \\
\hline $56-70$ & C (Enough) & 0 & 0 \\
\hline $46-55$ & D (Poor) & 0 & 0 \\
\hline $0-45$ & E (Failed) & 0 & 0 \\
\hline \multicolumn{2}{r}{ Total } & 71 & 100 \\
\hline
\end{tabular}

Based on the table, 45 students $(63.4 \%)$ were in the excellent category, 26 students (36.6\%) They were in the good category, and there were not enough students in the bad and failed category. Most of students were in excellent category. In brief, it is understood that students have various results of paragraph writing achievements which indicates that they have different paragraph writing categories.

\section{The Result of ICT Use Questionnaire}

The questionnaire of four-point Likert scale ranging from " 4 " to "1" was applied to know students' frequency of ICT usage by using questionnaire. There were 15 items that had been answered by the students in this research. After the researchers gave the questionnaire to the students, the highest score was 60 , the low score was 34 . The mean of 
this data was 51.87 and standard deviation was 8.032. The following table showed the students' frequency of ICT usage.

Table 2.

The Score Range of ICT Questionnaire

\begin{tabular}{|l|l|l|l|}
\hline Score & \multicolumn{1}{|c|}{ Category } & \multicolumn{1}{|c|}{$\begin{array}{c}\text { Number of } \\
\text { Students }\end{array}$} & $\begin{array}{c}\text { Percentage } \\
\text { (\%) }\end{array}$ \\
\hline $46-60$ & High & 50 & 70.4 \\
\hline $31-45$ & Medium & 21 & 29.6 \\
\hline $15-30$ & Low & 0 & 0 \\
\hline & Total & 71 & 100 \\
\hline
\end{tabular}

Based on that table, there were 50 students $(70.4 \%)$ in high category, there were 21 students (29.6\%) in medium category and there were not any student in low category. Much of the students were in the highest group.

\section{The Result of Learning Attitude Questionnaire}

The questionnaire of four-point Likert scale ranging from " 4 " to "1" was applied to know students' frequency of learning attitude usage by using questionnaire. There were 20 items that had been answered by the students in this research. After the researchers gave the questionnaire to the students, the highest score was 80 , the lowest score was 53 . The mean of this data was 71.32 and standard deviation was 6.761. The following table showed the students' frequency of learning attitude.

Table 3.

The Score Range of Learning Attitude Questionnaire

\begin{tabular}{|l|l|l|l|}
\hline \multicolumn{1}{|c|}{ Score } & \multicolumn{1}{|c|}{ Category } & \multicolumn{1}{|c|}{$\begin{array}{c}\text { Number of } \\
\text { Students }\end{array}$} & $\begin{array}{c}\text { Percentage } \\
\text { (\%) }\end{array}$ \\
\hline $61-80$ & High & 68 & 95.8 \\
\hline $41-60$ & Medium & 3 & 4.2 \\
\hline
\end{tabular}




\begin{tabular}{|c|l|l|l|}
\hline $20-40$ & Low & 0 & 0 \\
\hline & Total & 71 & 100 \\
\hline
\end{tabular}

Based on that table, there were 68 students (95.8\%) in high category, there were 3 students $(4.2 \%)$ in medium category and there were not any student in low category. Much of the students were in the highest group.

\section{Result of the Multi Regression Analysis}

The most recent result that will be addressed in this research is the association and involvement of ICT and learning attitudes towards writing. Based on the result, the modified R square was found to be 0.114 , which indicates that students' use of ICT and learning behaviours contributed $11.4 \%$ to their writing achievement. In addition, the significance value of the three variables was 0.006 rather than 0.05 . It can be inferred that there is a major link between the use of ICT, understanding and writing abilities of the Third Semester English Education Program Students at Universitas Sriwijaya.

\section{DISCUSSIONS}

There are several points that can be identified on the basis of the results of the study. Second, depending on the mathematical study, the relevant value was 0.006 lower than 0.05 , which indicates that there is a significant association between the use of ICT, Learning Mindset and Writing Success of Third Semester Students of the English Education Program at Sriwijaya University. The findings of the regression study indicate that there is an important contribution between the use of ICT, learning mindset, and writing achievement. The result revealed that the modified R square was 0.114 , which indicates that students were using ICT and learning attitude contributed $11.4 \%$ to their writing achievement.

There was a correlation because, in line with that the students feel confident in their ability to express ideas in writing. Based on students' writing achievement, most of the students were in excellent category. There were 45 students (63.4\%) who got A. There were 26 students 
(36.6\%) who got B. Students already know how to write a good paragraph with that skill.

Based on students' responses of their ICT questionnaire, there were 50 students $(70.4 \%)$ in high category. It was proved if students felt helpful by using ICT as they could write creatively and better in English as shown by Inderawati, Sofendi, Purnomo, Vianty, \& Suhendi (2019) that ICT really supports students to learn due to its facility. Not only that, by using ICT students could be focused, and also saved their time because it could make students easier to find information faster from everywhere and anytime (Inderawati, 2011). According to Uhomoibhi (2006), elearning helps students to get knowledge quicker at any time. The result of this association study was consistent with Alotumi (2014) who found that Facebook engagement helped students compose effectively. His research looked at Yemeni EFL Students' expectations, behaviors and difficulties of incorporating Facebook engagement to enhance their writing.

Last, based on students' responses about learning attitude, there were 68 students $(95.8 \%)$ in high category toward learning attitude. Moreover, depending on the student's response to the questionnaire on the table, most students did not agree to stop writing in English, but often they became nervous when their writing could be tested. It was because they found writing in English to be an enjoyable task and exempt from being judged, which meant that they wrote what they wanted to write and free of being commented by other readers. They also It acknowledged that writing in English was a lot of fun. Students loved writing in English and preferred to write their thoughts in a paper. Not just that, students have decided that it would be an enjoyable experience to discuss their writing in English with others on Facebook directly through the use of ICT as previously emphasized by Inderawati, Petrus, \& Jaya (2019).

\section{CONCLUSION}

On the basis of the findings of the above analysis, it can be inferred that the use of ICT, learning attitudes and academic paragraph writing by students are closely connected together. The use of ICT and learning attitude are viewed as the two factors affecting the students' success in academic paragraph writing. It implies that other factors give 
contributions to the students' success. Other factors that might affect students' success in writing are feeling anxious, fear of evaluation, and freedom of writing. Here, it is said that most of the students felt an enjoyment of writing, no fear of being scored or commented. The existence of writing as a fun activity does not lower students' motivation to express their ideas in written communication. Moreover, sharing or doing forum group discussion what they are writing on social media create new paradigm that writing is not that boring and complicated. Here, the application of ICT, to some extent, raise students' awareness of writing. At the end, it can be reported that ICT use and learning attitude contributed positively to the quality of students' writing.

\section{REFERENCES}

Apriani, E. (2016). A New Literacy: The role of technology to develop student's character. Ta'dib: Journal of Islamic Education (Jurnal Pendidikan Islam), 21(1), 59-72.

Apriani, E. (2017). THE MISUSE OF ICT BY STUDENTS: THE EFFECTS OF PHORNOGRAPHY AND THE TEACHER SOLUTIONS. Tadrib, 1(2), 185-203.

Retrieved from http://jurnal.radenfatah.ac.id/index.php/Tadrib/article/view/1 $\underline{046 .}$.

Apriani, E., \& Hidayah, J. (2019). The ICT Used by the English Lecturers for Non-English Study Program Students at IAIN Curup. Vision: Journal for Language and Foreign Language Learning, 8(1), 26-37.

Apriani, E., Supardan, D., Sartika, E., Suparjo, S., \& Hakim, I. N. (2019). Utilizing ICT to develop student's language ethic at Islamic university. POTENSIA: Jurnal Kependidikan Islam, 5(1), 1- 14.

Apriani, E. (2017). Utilizing Preservice English Teachers Strategies and Classroom Management at Junior High School in Rejang Lebong Regency. ENGLISH FRANCA: Academic Journal of English Language and Education, 1(2), 149-194.

Abas, I.H. and Aziz, N.H.A. (2016). Indonesian EFL students' perspective on writing process: A Pilot Study. Advances in Language and Literary Studies, 7 (3). 
Ajzen, I. (2005). Attitude, personality and behavior (2nd ed.). New York, NY: Open University Press.

Apriani, E. (2016). A New Literacy: The role of technology to develop student's character. Ta'dib: Jurnal Pendidikan Islam, 21(1), 59-72.

Apriani, E., Inderawati, R., Arianti, A., Wati, S., \& Hakim, I. N. (2021). Implementing E-learning Training toward English Virtual Lecturers: The Process, Perspectives, Challenges and Solutions. International Journal of Emerging Technologies in Learning, 16(4).

Aryanika, S. (2016). The correlation between the students' writing motivation and the writing ability. English Education: Jurnal Tadris Bahasa Inggris, 9(1), 2016, 215-232.

Ariyanti. (2016). The teaching of EFL writing in Indonesia. Dinamika Ilmu, $16(2), 2016$.

Aunurrahman., Hamied, F.A., \& Emilia, E. (2016). Exploring an academic writing class in an Indonesian university Context. Language Circle: Journal of Language and Literature, 11, 1-11.

Bidin, S. (2009). Motivation and attitude in learning English among students in the northern region of Malaysia. Journal of English Language Teaching

Brown, H. D. (2001). Teaching by principles. New York, NY: Addison Wesley Longman, Inc.

Choy, S. C., \& Troudi, S. (2006). An investigation into the changes in perceptions of and attitudes towards learning English in a Malaysian college. International Journal of Teaching and Learning in Higher Education, 18(2), 120-130.

Creswell, J. W. (2005) . Educational research: Planning, conducting, and evaluating quantitative and qualitative research (2th ed.). Boston, MA: Pearson Education, Inc.

Creswell, J. (2009). Research design: Qualitative, quantitative and mixed approaches ( $3^{\text {rd }}$ Ed). Thousand Oaks, CA: Sage Publications, Inc.

Creswell, J. (2012). Educational research planning, conducting, and evaluating quantitative and qualitative research ( $3^{\text {rd }}$ ed.). Upper Saddle River, NJ: Pearson Education, Inc. 
Daniels, P.T. \& Bright, W. (1996). The study of writing systems. London, UK: Oxford University Press, Inc.

Dehbozorgi, E. (2012). Effect of attitude towards language earning and risk-taking on EFL students' proficiency. International Journal of English Linguistics, 2, 41-48. doi:10.5539/ijel.v2n2p41.

Dudeney, G. (2000). The internet and the language classroom. Cambridge: Cambridge University Press.

Fajri, H, M., Inderawati, R. \& Mirizon, S. (2015). The implementation of peer editing technique to improve writing achievement. The Journal of English Literacy Education: The Teaching and Learning of English as a Foreign Language. 2 (2), 48-57.

Feng. R., \& Chen, H. (2009). An analysis on the importance of motivation and strategy in postgraduates English acquisition. English Language Teaching, 2, 93-97.

Finger, G., \& Trinidad, S. (2002). ICTs for learning: An overview of systemic initiatives in the Australian states and territories: Australian Educational Computing, 17(2), 3-14.

Graham, S., Berninger, V., \& Fan, W. (2007). The Structural Relationship between Writing Attitude and Writing Achievement in First and Third Grade Students. Contemporary Educational Psychology, 32, 516-536.

Hashemian, M., \& Heidari, A. (2013). The Relationship between L2 Learners' Motivation/Attitude and Success in L2 Writing. Procedia - Social and Behavioral Sciences, 70, 476-489.

Inderawati, R. (2011). From classroom to peer comment in Facebook: Bridging learners' literacy. Paper presented in the $4^{\text {th }}$ International Conference ICT for Language Learning. Pixel, Italy.

Inderawati, R. (2017). The dynamics of EFL teaching in Indonesia: Be innovative teachers through social media. English Language Teaching and Research, 1(1), 29-37.

Inderawati, R., Petrus, I. \& Jaya, H.P. (2019). Exploring and identifying technology-based dynamic learning through social media in academic writing. English Community Journal, 3 (1): 317-324

Inderawati, R., Sofendi, Purnomo, M. E., Vianty, M., \&Suhendi, D. (2019). Students' engagement in utilizing technology for learning support. 
ENGLISH FRANCA: Academic Journal of English Language and Education. 3 (2), 181-195

Kara, A. (2009). The effect of a "Learning Theories' unit of students attitude toward learning. The Australian Journal of Teacher Education. 34(3).

Luo, H. \& Lei, J. (2012). Educational stages and interactive learning: From kindergarten to workplace training. 73-91. China: Peking University Press. Retrieved from 10.4018/978-1-4666-01376.ch005..

Muslim, I. M., (2012). Helping EFL students improve their writing. International Journal of Humanities and Social Science, 4(2), 105112.

Nunan, D. (1999). Second language teaching and learning. Boston: Heinle \& Heinle Publishers.

Patton, M. (2006). Qualitative research and evaluation methods. Thousands Oaks, CA: Sage Publication, Inc.

Pelgrum, W. J. (2001). Obstacles to the integration of ICT in education: results from a worldwide educational assessment: Computers \& Education, 37, 163-178.

Sanjaya, H. K., Apriani, E., \& Edy, S. (2020). Using Web Blog for EFL Students in Writing Class. Using Web Blog for EFL Students in Writing Class, 4(04), 516-535.

Selwyn, N. (2003). ICT in non-formal youth and adult education: defining territory. Philadelphia: OECD/NCAL International roundtable Retrieved from http://www.literacy.org/ICTconf/OECD Selwy n final.pdf.

Scrivener, J. (2011). Learning teaching: The essential guide to English Language Teaching ( $3^{\text {rd }} \mathrm{Ed}$ ). Basingstoke, HPH: MacMillan.

Sicilia, C. (2005). The challenges and benefits to teachers' practices in constructivist learning environments supported by technology. Unpublished master's thesis, McGill University, Montreal.

Setyowati, L. \& Sukmawan, S. (2016). EFL_Indonesian Students' Attitude toward Writing in English. Arab World English Journal (AWEJ). 7 (4). 365-378. 
Sliwka, A. (2003). Networking for educational innovation: A comparative_analysis. Networks of innovation: Towards new models for managing _ schools and systems, $\quad 49-63$.

Sujannah, W.D. \& Cahyono, B.Y. (2017). The effect of self- selected topic and checklist-based peer feedback on Indonesian EFL students' writing ability. International Journal of English Language Teaching, 4 (2); 2017.

Tinio, V. (2002). ICT in education. New York, NY: United Nation Development Program.

Toomey, R. (2001). Schooling issues digest no 2: Information and communication technology for teaching and learning. Retrieved from http://www.dest.gov.au/schools/publications/2001/digest/tech 